\title{
Ortaokul Öğrencilerinin Organ Bağışına ve Nakline Yönelik Görüşlerinin İncelenmesi
}

\section{Middle School Students' Opinions about Organ Donation and Transplantation}

\author{
Seda TETİK*
}

\author{
Ümran Betül CEBESOY**
}

Accepted: 28 March 2018

\begin{abstract}
Raising informed generations about organ donation and organ transplantation is possible with informing students about organ donation from beginning of early ages. Based on this reason, the aim of this study is to explore middle school students' opinions about organ donation and transplantation. A total of 272 middle school students from three different schools in Usak city participated in the study. After literature review, a questionnaire which was prepared by the authors was administrated to the students. Descriptive analysis (frequencies and percentages) was used for data analysis. The results revealed that more than half of the students were not knowledgeable about organ donation $(61 \%)$ and the required conditions about organ donation (71\%). In addition, while most of the students were aware about the donation of organ like kidney, liver or heart, they were unaware about the transplantation of cornea and bone marrow. While most of students indicated that they would like to donate their organs because of 'saving life', 'helping people' and 'religious beliefs'; some students indicated they would not donate their organ as because they were afraid of 'deterioration of their body integrity' and 'their family would not allow'.
\end{abstract}

Keywords: opinions, science course, organ donation, organ transplantation, middle school students, socioscientific issues.

ÖZ: Öğrencilerin küçük yaşlardan itibaren organ bağışı ve nakli konusunda farkındalıklarının artırılması organ bağışı konusunda daha bilinçli bireyler yetiştirilmesi açısından önem arz etmektedir. Buradan yola çıkılarak çalışmanın amacı ortaokul öğrencilerinin organ bağışına ve organ nakline yönelik görüşlerini ortaya çıkarmaktır. Araştırmada nicel verilere dayalı betimsel tarama yöntemi kullanılmıştır. Araştırmanın çalışma grubunu 2016-2017 öğretim yılında Uşak ilinde öğrenim gören üç farklı okuldan 272 ortaokul öğrencisi oluşturmaktadır. Araştırmada veri toplama aracı olarak araştırmacılar tarafından ilgili alayazın taranarak oluşturulmuş anket formu kullanılmıştır. Verilerin analizinde ise betimsel analiz (yüzde ve frekans analizi) kullanılmıştır. Araştırmaya katılan öğrencilerin önemli bir kısmı organ bağışı konusunda bilgi sahibi olmadığını ifade ederken (\%60), organ bağışı için gerekli şartları bilmediğini belirten öğrenciler çoğunluktadır (\%71). Öğrencilerin büyük çoğunluğu böbrek, karaciğer ve kalp gibi organların nakledildiğini düşünürken kemik iliği ve kornea naklinin gerçekleştiğini ifade eden öğrenci sayısı daha azdır. Öğrencileri büyük çoğunluğu organ naklini 'hayat kurtarma', 'dini duygular' ve 'insanlara yardımcı olma amacıyla organ bağışında bulunmak istediğini ifade ederken; 'vücut bütünlüğünün bozulmaması' ve 'ailesi onaylamayacağı' için organ bağışında bulunmak istemeyen öğrenciler de bulunmaktadır.

Anahtar kelimeler: görüşler, fen bilimleri dersi, organ bağışı, organ nakli, ortaokul öğrencileri, sosyobilimsel konular.

* Science Teacher, Ministry of National Education, Usak, Turkey, sedaaaisik@gmail.com

${ }^{* *}$ Corresponding Author: Dr. Lecturer, Usak University, Uşak, Turkey, ubetulcebesoy@gmail.com

Citation Information

Tetik, S., \& Cebesoy, Ü. B. (2018). Ortaokul öğrencilerinin organ bağışına ve nakline yönelik görüşlerinin incelenmesi. Kuramsal Eğitimbilim Dergisi [Journal of Theoretical Educational Science], 11(3), 486-506. 


\section{Giriş}

Sosyobilimsel konular, 2013 yılında yenilenen ortaokul fen bilimleri öğretim programına girmiştir. Sosyobilimsel konular, genellikle tek bir çözümü bulunmayan, açık uçlu ve çözümünde etik, ahlaki, hukuki pek çok bakış açısının rol oynadığı konulardır (Sadler \& Zeidler, 2004; 2005). Sosyobilimsel konular arasında genetik testler, genetiği değiştirilmiş organizmalar, kök hücre çalışmaları gibi pek çok konu bulunmaktadır (Klop \& Severiens, 2007; Sadler \& Zeidler, 2004; 2005). Organ bağış1 ve nakli konusu da bireyler için tek bir cevabı bulunmadığı, bazı sosyal, kültürel ikilemler barındırdığı için sosyobilimsel konular arasında yer almaktadır (Evren Yapıcıoğlu, 2016; Harman \& Çökelez, 2017; Toraman \& Aydın, 2013).

İnsanlar hayatlarının belli dönemlerinde sağlı problemleri ile karşılaşırlar. Organ yetmezliği de insanların yaşadığı sağlık problemlerinden biridir. Organ nakli ise organ yetmezliğine karşı başarılı bir tedavi yöntemidir. Organ nakli, vücutta görevini herhangi bir nedenden ötürü yapamayan bir organın yerine canlı vericiden veya kadavradan alınan sağlam ve aynı görevi üslenecek bir organın nakledilmesi işlemidir (Sıpkın, Şen, Akan, \& Malak, 2010). Kalp, karaciğer, böbrek, pankreas, ince bağırsak, kemik iliği, kan, deri, kornea gibi yaşamsal önemi olan pek çok organın nakli gerçekleştirilebilmektedir (Özmen, Çetinkaya, Sarızeybek, \& Zeybek, 2007). Günümüzde, 18 veya üstünde bir yaşta olup akli dengesi yerinde olan herkes organ bağışında bulunabilir (Balcı \& Şahingöz, 2014). Batı ülkelerinde organ nakilleri sıklıkla kadavradan sağlanırken ülkemizde organ naklinde kullanılacak organlar ağırlıklı olarak canlı donörlerden (verici) özellikle de hastanın yakınlarından sağlanmaktadır (Özdağ, 2004). Geri dönüşü olmayacak şekilde beyin ölümü gerçekleşen ve hastane koşullarında ölen kişilerin organları, ilgili uzmanların beyin ölümü tanısı koyması sonrasında ailesinin izin vermesiyle nakil edilebilir (Kara, Salman, \& Öngel, 2012).

Organ naklinin başarılı bir şekilde gerçekleşmesi için en gerekli unsur donörlerdir. Nitekim, Burra ve diğerleri (2005) organ bağışındaki en önemli problemin organ bağışının azlığı olduğunu ifade etmiştir. Dolayısıyla bireylerin organ bağışına yönelik görüş ve tutumları önem kazanmaktadır. Yurt içinde yapılan çalışmalarda pek çok kesimden bireyin organ bağışına yönelik tutumları ve görüşleri incelenmiştir. Örneğin, hemşirelerin (Aytaş, Ünal, \& Kartalc1, 2011; Balc1 \& Şahingöz, 2014), sağlık personelinin (Efil, Şişe, Üzel \& Eser, 2013; Kara, Salman, \& Öngel, 2012), tıp fakültesi öğrencilerinin (Koçak, Aktaş, Şenol, Kaya, \& Bilgin, 2010; Toru \& Ayada, 2014), hemşirelik bölümünde öğrenim görmekte olan öğrencilerin (Demir Doğan, Uzun, Kaya, Ekinci, \& Altınkaynak, 2016; Savaşer, Mutlu, Çağlar, Doğan, \& Canbulat, 2012; Özer ve diğerleri, 2008; Yaşar ve diğerleri, 2008; Yazıcı, Kavak, Kaya, Tekin, \& Kalayc1, 2015), üniversitede öğrenim gören lisans ve yüksek lisans öğrencilerinin (Bölükbaş1, Eyüpoğlu, ve Kurt, 2004; Kılıç, Koçak, Türker, Gürpınar, \& Gülerik, 2010; Kavurmacı, Karabulut, \& Koç, 2014; Özpulat, 2017; Sezek ve diğerleri, 2015), öğretim üyelerinin (Sıpkın ve diğerleri, 2010), hasta yakınlarının (Özkan \& Yılmaz, 2009) ve halkın (Şen \& Özaydın, 2004) görüşleri incelenmiştir. Araştırmalardan elde edilen bulgular farklılık göstermektedir. Örneğin; sağlıkla ilgili bölümlerde öğrenim görmekte olan öğrencilerin organ bağışı ve organ nakli konusundaki bilgi düzeylerinin yeterli olduğu (Aytaş ve diğerleri, 2011) belirlenirken Yaşar ve diğerleri (2008) yaptıkları çalışmada öğrencilerin bilgi düzeylerinin yetersiz olduğunu belirlemişlerdir. Çalışmalar genelde katılımcıların organ bağışına yönelik olumlu fikirlere sahip olduklarını göstermektedir (Demir Doğan 
ve diğerleri, 2016; Kılıç, Koçak, Türker, Gürpınar, \& Gülerik, 2010). Yine çalışmaların ortak bulguları, katılımcıların organ bağışını "başkalarının hayatlarını kurtarmak", "hasta bireyleri sağlığına kavuşturmak", "çürüyüp gidecek organların işe yaraması", "insanlığa hizmet” şeklinde gördüklerini belirlemiştir (Demir Doğan ve diğerleri, 2016; Bölükbaş1 ve diğerleri, 2004; Cebeci, Sucu-Dağ, \& Karazeybek, 2015; Kılıç ve diğerleri, 2010; Koçak ve diğerleri, 2010; Özer ve diğerleri, 2008). Organ bağış1 konusunda kararsız olan veya olumsuz tutumları olan katılımcılar ise kararlarının nedenini "vücut bütünlüklerinin bozulacağı", "sağlık personeline güvenmemeleri", "vicdanen rahat olmamaları", "yetersiz bilgilendirme", "dinen sakıncalı olması" ve "örf adetlerin baskısı" gibi sebeplerle açıklamışlardır (Çetin \& Harman, 2012; Kavurmacı ve diğerleri, 2014; Kılıç ve diğerleri, 2010; Sıpkın ve diğerleri, 2010; Toru \& Ayada, 2014). Çalışmaların diğer bir ortak bulgusu ise eğitimli bireylerin organ bă̆ışı konusunda daha istekli olmaları ve olumlu tutumlara sahip olmalarıdır (Aytaş ve diğerleri, 2011; Kavurmacı ve diğerleri, 2014; Öztürk Emiral ve diğerleri, 2017; Yaşar ve diğerleri, 2008). Bu bulgular, uluslararası alanyazında rapor edilen bulgularla da örtüşmektedir (Bedi ve diğerleri, 2015; Burra ve diğerleri, 2005; Figueroa, Mesfum, Acton, \& Kunst, 2013; Siebelink, Albers, Roodbol, \& van de Wiel, 2002; Siebelink, Geerts, Albers, Roodbol, \& van de Wiel, 2011; Siebelink, verhagen, Roodbol, Albers, $\&$ van de Wiel, 2017). Örneğin, Burra ve diğerleri (2005) tıp öğrencileri ile gerçekleştirdikleri çalışmada, öğrencilerin önemli bir kısmının (\%96) organ bağışına karşı pozitif tutum içinde olduklarını ve \%88'inin ise öldükten sonra organlarını bağışlamak istediklerini rapor etmişlerdir. İngiltere'deki Tıp fakültesi öğrencileri ile çalışan Bedi ve diğerleri (2015), öğrencilerin organ bağışına yönelik pozitif tutum içerisinde olduklarını ancak bilgilerinin sınırlı olduğunu ifade ettiklerini belirtmişlerdir. Farklı dokuların nakil durumları hakkında bilgi sahibi olma düzeyleri karşılaştırıldığında öğrencilerin önemli bir kısmının böbrek (\%92), kalp (\%89) ve karaciğer (\%86.5) naklinden haberdar olduğu ancak ince bağırsak (\%37) ve Langerhans adacıkları (\%33) naklini bilen öğrencilerin ise daha az sayıda olduğunu belirlemişlerdir.

$\mathrm{Bu}$ çalışmaların hedef kitlesi yetişkin bireyler olmakla birlikte gerek yurt içinde gerekse yurt dişında öğrencilerle gerçekleştirilen çalışmalar bulunmaktadır (Gökçe, Özer, \& Kilci, 2016; Siebelink ve diğerleri, 2002, 2011, 2017; Sanner, 2002). Gökçe, Özer ve Kilci (2016), 7. sınıf öğrencileri ve aileleri ile yapmış olduğu nitel çalışmada sosyal bilgiler dersinde öğrencilerin organ bağışına yönelik görüşleri incelemiş olup öğrencilerin çoğunlukla organ bağışını hayat kurtarma olarak gördüğünü, yardımlaşma ve paylaşma duygularını güçlendirdiğini düşündüklerini belirtmiştir. Diğer bir çalışmada, Sanner (2002) İsveçli öğrencilerin organ bağışı konusundaki farkındalıklarını incelemiş ve öğrencilerin organ bağışı konusunda endişe duymakla birlikte, organ bağışının önemli olduğunu düşündüklerini ortaya koymuştur. Siebelink ve diğerleri (2011) 12-15 yaş aralığındaki çocukların organ bağışı konusunda düşünebilecek yetilere sahip olduğunu ve bu konuda düşünmeye istekli olduğunu belirlemiştir. Organ bağışını evinde hiç konuşmayan öğrencilerin oranı \%32 iken, öğrencilerin \%43'ü organ bağışını evlerinde konuşma imkânı bulduklarını ve \%66'sının organ bağışında bulunmak istediklerini ifade etmişlerdir. Siebelink ve diğerleri (2017) yaptıkları daha güncel bir çalışmada, organ bağışı ile ilgili öğrencileri bilgilendirmek için en iyi yaş aralığının 10-11 yaş aralığı olduğunu ifade etmiştir. 
Öğrencilerle gerçekleştirilen çalışmaların bir boyutu da organ bă̆ışı ve nakli konusunda öğrencileri bilgilendirme amaçlı hazırlanan eğitsel programlardır. Milaniak, Przybylowski, Wierzbicki ve Sadowski (2010), eğitsel programların genç insanların organ bağışı konusunda dikkatini çekerek onları organ bağışına yönlendirebileceğini ifade etmişlerdir. Örneğin Milaniak ve diğerleri (2010) yaptıkları organ bağışına yönelik bir eğitim uygulaması sonucunda katılımcıların organ bağışı kartı imzalama durumlarını incelemiştir. Uygulama öncesinde organ bağışı beyanında bulunanların sayısı \%8 iken bu uygulama sonrasında katılımcıların \%90'nından fazlası organ bağışında bulunmak istemiş ve \%78'i ise organ bağışı beyanında bulunmuştur. Benzer şekilde Reville ve diğerleri (2013), geliştirdikleri eğitim programına katılan lise öğrencilerinin nakil olabilecek organ ve dokuları belirlemede daha başarılı olduklarını dolayısıyla organ bağışı konusundaki bilgilendirici eğitsel programlarının etkili olduğunu, özellikle bu programlarının çeşitli sağlı kuruluşları ile ortaklaşa yapılması sonucunda bu tür eğitim programlarının etkisinin artacağını ifade etmişlerdir. Shu ve diğerleri (2011), organ bağışı konusunda farkındalığı arttırmaya yönelik geliştirilen eğitsel programların lise öğrencilerinin organ bağışına yönelik tutumlarını olumlu yönde etkilediğini belirlemişlerdir. Siebelink ve diğerleri (2017) yaptıkları bir çalışmada ilkokul öğrencilerine yönelik organ bağışı konusunda farkındalıklarını arttırmak amacıyla bir eğitim programı geliştirmiş ve uygulanan bu eğitim programı sonrasında öğrencilerin aileleriyle organ bağışının önemi konusunda konuşma oranlarında \%20 artış olmuştur. Yani program öncesiyle kıyaslandığında, program sonrasında \%20 daha fazla öğrenci bu konuyu aileleriyle konuşmuşlardır. Benzer durum Türkiye'de gerçekleştirilen çalışmalarda da görülmüştür. Örneğin Tarhan ve diğerleri (2012) lise son sınıf öğrencileri $(\mathrm{N}=845)$ ile gerçekleştirdikleri çalışmada öğrencilerin \% $\% 58$ 'inin organ bağış1 konusunda yeterli bilgiye sahip olduğunu ancak bilgilendirme amacıyla gerçekleştirilen uygulama sonrasında öğrencilerin \%84'ünün konuyla ilgili yeterli bilgiye sahip olduğunu ve \%81'inin ise organ nakli ve bağışını onayladığını tespit etmiştir. Yapılan diğer bir çalışmada, Çetin ve Harman (2012) lise öğrencilerinin organ bağışı ve nakli konusundaki bilgi ve tutumlarını inceledikleri çalışmada, öğrencilerin az bir kısmının (\%30) organ bağışı ve nakli konusunda bilgi sahibi olduklarını ve sadece \%43'ünün organ bağışını dinen sakıncalı bulmadıklarını belirlemişlerdir. Araştırmacılar, öğrencilerin organ bağışı konusundaki bilgi eksikliklerinin nedenini aldıkları eğitimin yetersiz olması, aile ve toplum baskısı ya da dini sebeplerden ve endişelerden kaynaklandığını ifade etmişlerdir.

\section{Problem Durumu}

Yapılan çalışmalar hem öğretmenlerin hem de öğrencilerin organ bağışı ve organ nakli konularına fen bilimleri programında yer verilmesi gerektiğini düşündüklerini ortaya koymuştur (Sanner, 2002; Siebelink ve diğerleri, 2017). Benzer şekilde Siebelink ve diğerleri (2017), Organ bağışı ve nakli konusunda bir eğitim programı uygulamak ya da öğrencileri bu konuda bilgilendirmek için en iyi yaş aralığı 10-11 yaş aralığ1 olduğunu ifade etmiştir. Dolayısıyla bu konuların fen bilimleri programlarına ortaokul döneminden itibaren dahil edilmesi önem kazanmıştır. Bu durum, yenilenen 2013 ve 2017 fen bilimleri öğretim programlarının da şekillenmesinde rol oynamıştır. Organ bağışının önemi, hem 2013 hem de 2017 fen bilimleri öğretim programındaki kazanımlar arasında verilmiştir. Organ bağısına yönelik olarak 'Organ bağışının toplumsal dayanışma açısından önemini kavrar’ şeklindeki kazanım 2013 fen 
bilimleri programında 7. Sınıf kazanımları içerisinde yer alırken, aynı kazanım, 2017 fen bilimleri ögretim programında 6. Sınıf kazanımları arasında yer almakta dolayısıyla daha erken yaşlardan itibaren öğrencilerin organ bağışına yönelik farkındalıkları arttırılması hedeflenmektedir (Milli Eğitim Bakanlığı [MEB], 2013; 2017).

Bazı öğretmenler, organ bağışı ve organ nakli konularının ilköğretim düzeyinde öğretilmesini, çocukların yaşlarının uygun olmadığı gerekçesi ile onaylamadıklarını ifade ederken, öğretmenlerin önemli bir kısmı da bu konuyla ilgili eğitim materyallerini sınıflarında uygulamaya istekli olduklarını belirtmişlerdir (Siebelink ve diğerleri, 2017). Yine Siebelink ve diğerleri (2011) bu konuların özellikle küçük yaşlardan itibaren gündeme gelmesi gerektiğini çünkü ebeveynlerin çocuklarının herhangi bir sebepten ötürü beyin ölümü gerçekleşmesi durumunda organlarını bağışlamakta zorluk çektiklerine dikkat çekmiş ve çocuklarının organ bağışı konusundaki fikirlerini ebeveynlerinin bilmesi gerektiğini belirtmiştir. Böyle bir kararla yüz yüze gelmeleri durumunda, ebeveynlerin çocuklarının organlarını bağışlama kararını daha kolay verebileceklerini ifade etmiştir. Nitekim var olan çalışmalarda eğitimli bireylerin bu konudaki farkındalıklarının daha yüksek olduğunu ortaya koymaktadır (Barcellos, Arauio, \& Costa, 2005; Öztürk Emiral ve diğerleri, 2017). Dolayısıyla bu konuların erken yaşlardan itibaren fen bilimleri programlarına dahil edilerek bu konuda öğrencilerin farkındalıklarının artırılması önem arz etmektedir. Buradan yola çıkılarak organ bağışı hakkında ortaokul öğrencilerinin organ bağışı ve organ nakli hakkında neler bildiğini belirlemek amacıyla gerçekleştirilen bu çalışmada aşağıdaki araştırma sorusuna cevap aranmıştır: nelerdir?

Ortaokul öğrencilerinin organ bağışı ve organ nakli konusundaki görüşleri

\section{Yöntem}

Çalışma, nicel araştırma yöntemlerinden tarama modeli kullanılarak tasarlanmıştır. Bu modelin tercih edilmesinin amacı belirli bir grubun çeşitli özellikleri hakkında bilgi edinmektir. Tarama modelinde kullanılabilecek farklı türler bulunmakta beraber bu araştırmada, verilerin belirli bir çalışma grubundan belirli bir zaman dilimi içerisinde toplandığ kesitsel tarama yöntemi tercih edilmiştir (Fraenkel, Wallen, \& Hyun, 2011).

\section{Çalışma Grubu}

Araştırmanın çalışma grubunu, 2016-2017 öğretim yılı bahar döneminde Uşak ilinde bulunan üç okuldaki toplam 272 ortaokul öğrencisi oluşturmaktadır. Bu okulların seçiminde ulaşılabilirlik ve zaman gibi çeşitli durumlar göz önüne alındığından elverişli örnekleme metodundan yararlanılmıştır (Fraenkel ve diğerleri, 2011). Verilerin toplandığı dönemde, organ bağışının önemine yönelik kazanım 6. Sınıf programında yer aldığından dolayı, bu konunun tamamlandığı 6., 7., ve 8. Sınıf öğrencileri bu çalışmaya dahil edilmiştir.

\section{Veri Toplama Araçları}

Verilerin toplanması için araştırmacılar tarafından ilgili alanyazından yararlanılarak oluşturulmuş anket formu kullanılmıştır (Altınkaynak ve diğerleri, 2016; Bulletin, 2011; Aytaş ve diğerleri, 2011; Bölükbaş1 ve diğerleri, 2004; Kara ve diğerleri, 
2012; Kılıç ve diğerleri, 2010; Koçak ve diğerleri, 2010; Özer ve diğerleri, 2008; Özkan \& Yılmaz, 2009; Şen \& Özaydın, 2004; Sıpkın ve diğerleri, 2010; Yaşar ve diğerleri, 2008). Anket formunun ilk bölümü öğrencilerin demografik özelliklerine yönelik sorular içermektedir. Bu demografik özellikler; cinsiyet, anne- baba eğitim düzeyi, gelir durumu, yerleşim yeri ve ailede kronik hastalığın bulunma durumudur. İkinci bölümü ise öğrencilerin; organ bağışına ilişkin bilgilerini değerlendiren ve düşüncelerini ifade etmelerine olanak sağlamak üzere oluşturulmuş açık uçlu sorulardan oluşmaktadır. Açık uçlu sorular oluşturulduktan sonra sosyobilimsel konularla ilgili olarak doktorasını tamamlamış iki fen bilimleri eğitimi uzmanından uzman görüşü alınarak soruların geçerliliği sağlanmıştır.

\section{Verilerin Analizi}

Anketin ilk bölümünde yer alan demografik verilerin analizi ve yorumlanmasında, betimsel istatistikten (yüzde ve frekans analizi) yararlanılmıştır. Anketin ikinci bölümünde yer alan açık uçlu sorulara verilen cevaplar ise betimsel analiz yöntemiyle (Strauss \& Corbin, 1994) sistematik bir biçimde incelenmiştir. Açık uçlu soruların cevapları, ilgili alanyazın temel alınarak belirlenen temalar çerçevesinde araştırmacılar tarafından bağımsız olarak kodlanmıştır. Bu kodlama sürecinde öncelikle soruların belirlenmesinde yararlanılan çalışmalarda oluşturulan kodlar belirlenmiş ve veriler bu kodlara göre analiz edilmiştir. İlk 30 öğrenci cevabının bağımsız kodlanması sonrası araştırmacılar bir araya gelerek belirledikleri temaları karşılaştırmış ve görüş ayrılığı ile görüş birliği olan durumlar üzerinde tartışıldıktan sonra fikir birliği sağlanmış araştırmacılar arası kodlayıcı güvenilirliği, elde edilen tüm veriler için Miles ve Huberman'ın (1994) önerdiği Güvenirlik = Görüş Birliği / (Görüş Birliği + Görüş Ayrılı̆̆ı) formülü kullanılarak \%95 olarak bulunmuştur.

\section{Bulgular}

$\mathrm{Bu}$ bölümde araştırmada elde edilen demografik verilere ve açık uçlu sorulardan elde edilen öğrenci cevaplarına ilişkin bulgular sunulacaktır. Öğrencilerin demografik bilgilerine ilişkin bulgular Tablo 1'de sunulmuştur:

Tablo 1

Öğrencilerin Demografik Özellikleri

\begin{tabular}{lcc}
\hline Tanitıcı özellikler & Frekans (f) & Yüzde (\%) \\
\hline Cinsiyet & 118 & \\
Kız & 154 & 43.4 \\
Erkek & & 56.6 \\
\hline Yerleşim & 16 & \\
Köy & 181 & 5.9 \\
Kasaba & 6 & 66.5 \\
İlçe & 69 & 2.2 \\
İl Merkezi & & 25.4 \\
\hline Aylık Gelir Durumu & 56 & \\
$0-750$ TL & 79 & 20.6 \\
$750-1500$ TL & & 29.0 \\
\hline
\end{tabular}




\begin{tabular}{lcc}
\hline $1500-2250 \mathrm{TL}$ & 56 & 20.6 \\
$2250-3000 \mathrm{TL}$ & 20 & 7.4 \\
3000 ve Üzeri & 61 & 22,4 \\
\hline Baba Ĕ̆itim Düzeyi & & \\
İlköğretim & 72 & 26.5 \\
Ortaokul & 91 & 33.5 \\
Lise & 72 & 26.5 \\
Üniversite & 37 & 13.6 \\
\hline Anne Eğitim Düzeyi & & \\
İlkokul & 95 & 34.9 \\
Ortaokul & 101 & 37.1 \\
Lise & 51 & 18.8 \\
Üniversite & 25 & 9.2 \\
\hline
\end{tabular}

\section{Babada Kronik hastalık olma} durumu

$\begin{array}{lcc}\text { Var } & 19 & 7 \\ \text { Yok } & 253 & 93\end{array}$

Annede Kronik hastalık olma

durumu

\begin{tabular}{lcc} 
Var & 27 & 9.9 \\
Yok & 245 & 90.1 \\
\hline $\begin{array}{l}\text { Organ Bağısıı Bekleyen } \\
\text { Yakınınız var mı? }\end{array}$ & \\
\hline Evet & 13 & 4.8 \\
Hayır & 259 & 95.2 \\
\hline Organ Bağısında Bulunan & & \\
Yakın var mı? & 25 & 9.2 \\
Evet & 247 & 90.8 \\
Hayır &
\end{tabular}

Tablo 1 incelendiğinde, çalışmaya katılan öğrencilerin \%43.4'ü kız ve \%56.6'sının erkek olduğu görülmektedir. Katılımcıların büyük bir kısmı kasabada yaşadığını ifade ederken (\%66.5), \%25.4'ü ise şehir merkezinde yaşadıklarını belirtmişlerdir. Katılımcıların aile gelir seviyeleri incelendiğinde, hemen her gelir düzeyinden yaklaşık olarak benzer yüzdelerde gelir düzeyine sahip öğrencilerin bulunduğu görülmektedir. Katılımcıların \%29'unun gelir durumu 750-1500 TL arasında iken \%22.4'ünün ise $3000 \mathrm{TL}$ ve üzeridir. Öğrencilerin annelerinin ve babalarının eğitim durumları incelendiğinde ise katılımcıların yarısından fazlasının (\%60) babalarının ilkokul veya ortaokul mezunu olduğu, \%26.5'inin lise mezunu ve $\% 13.5$ 'inin ise üniversite mezunu olduğu görülmektedir. Çalışmaya katılan öğrencilerin önemli bir kısmının (\%72) annesinin ilkokul veya ortaokul mezunu olduğu görülürken, annesi üniversite mezunu olan öğrencilerin sayısı azdır (\%9.2). Katılımcılara ayrıca, anne ve babalarında kronik hastalık olup olmama durumu sorulmuş katılımcıların büyük 
çoğunluğunun annesi (\%90.1) ve babası (\%93) kronik hastalığı bulunmadığını ifade etmiştir. Son olarak katılımcılara organ bağışı bekleyen veya organ bağışında bulunan yakını olup olmadığı sorulmuş olup katılımcıların önemli bir kısmı (\%95.2) organ bağışı bekleyen bir yakınları olmadığını ifade ederken sadece \%9'u bir yakınlarının organ bağışında bulunduğunu belirtmişlerdir.

Katılımcılara daha sonra çeşitli sorular yöneltilerek organ bağışına yönelik bilgi düzeyleri ortaya çıkarılmaya çalışılmıştır. Elde edilen bulgular Tablo 2'de sunulmuştur:

Tablo 2

Öğrencilerin Organ Bağışına Yönelik Bilgi Durumu $(N=272)$

\begin{tabular}{l}
\hline Bilgi düzeyi \\
\hline $\begin{array}{l}\text { Organ Bağışıının Ders Programında Yer Alma Durumu hakkında bilgi } \\
\text { sahibi olma }\end{array}$
\end{tabular}

Evet

$\begin{array}{cc}\underset{(f)}{\text { Frekans }} & \text { Yüzde } \\ (\%) & \end{array}$

Hayır

60

21.1

Bilgim yok

142

52.2

Organ Bağışı Konusunda Gerekli Şartları Bilme

Evet

70

25.7

Hayır

79

Organ Bağışı Hakkında Bilgi Sahibi olma

Evet

Hayır

161

Organ Bağışı Hakkında Bilgi

Kaynakları * $(\mathbf{n}=563)$

Ders Kitab1

Organ Bağış Merkezi

Dergi ve Gazete

İnternet

Televizyon

Diğer

\section{Bağışlanabilen Organ*(n=694)}

Böbrek

Karaciğer

Kornea

Kalp

Hepsi 


\begin{tabular}{lcc}
16 & 10 & 3.7 \\
18 & 184 & 67.6 \\
20 & 20 & 7.4 \\
22 & 10 & 3.7 \\
25 & 48 & 17.6 \\
\hline Organ Bağışı Hakkında Bilgi Alma İsteği & & \\
Evet & 210 & 77.2 \\
Hayır & 62 & 22.8 \\
\hline Organ Bağışı Hakkında Bilgi Alınmak istenen Kişi* $(\mathbf{n}=\mathbf{3 1 0})$ & & \\
Doktor & 182 & 66.9 \\
Hemşire & 44 & 16.2 \\
Din Görevlisi & 5 & 1.8 \\
Hepsi & 79 & 29.0
\end{tabular}

*Birden çok seçenek işaretlenmiştir.

Tablo 2 incelendiğinde, öğrencilerin konuya ilişkin bilgiyi daha çok televizyondan $(\% 57.7)$ ve internetten $(\% 55.9)$ edindikleri görülmüştür. Öğrencilerin \%32.7'si ders kitaplarından, \%30.9'u dergi ve gazetelerden ve \%15.1'i ise organ bağış1 merkezlerinden bilgi edindiklerini ifade etmişlerdir. Öğrencilerin \%59.2'si organ bağış1 konusunda yeterli bilgiye sahibi olmadığını ifade ederken, \%71'i de organ bağışı için gerekli şartları bilmediğini belirtmiştir. Ayrıca bağışlanabilecek organlar sorusuna öğrencilerin \%74.3'ü böbrek, \%60.7'si karaciğer, \%47.8'i kalp, \%24.3'ü kemik iliği, $\% 16.2$ 'si kornea ve \%32'si hepsi yanıtını vermiştir. Öğrencilerin \%67.6's1 18 yaşını doldurunca, \%17.6'sı ise 25 yaşını doldurunca organ bağışında bulunulabileceğini düşünmektedir. Ayrıca öğrencilerin \%52.2'si organ bağışı konusunun ders programında olmadığını ifade ederken, \%25.7'si bu konun programda geçip geçmediği ile ilgili bilgisinin olmadığını belirtmiştir. Öğrencilerin sadece \%20'si organ bağışı ve organ nakli konusunun programda bulunduğunu ifade etmiştir. Çalışmada öğrencilerin \%77.2'sinin organ bağışı konusunda bilgi almak istediği ve bu bilgiyi \%66.9'u doktorlardan, \%16.2'si hemşirelerden, \%1.8'i din görevlilerinden ve \%29'unun ise hepsinden bilgi almak istediği ifade etmiştir.

Son bölümde ise öğrencilere organ bağışlamayı düşünüp düşünmedikleri, organ bağışının hakkında ne düşündükleri ve organ bağışı konusunda neler bildikleri sorulmuştur. Öğrencilerin cevaplarından elde edilen temalar Tablo 3'te sunulmuştur: 
Tablo 3

Öğrencilerin Organ Bă̆ışına Yönelik Görüşleri (N=272)

\begin{tabular}{|c|c|c|c|}
\hline \multicolumn{2}{|c|}{ Öğrencilerin Organ Bağışı Konusundaki Düşünceleri } & Frekans (f) & Yüzde (\%) \\
\hline \multicolumn{4}{|c|}{ Organlarınızı bağışlamayı düşünür müsünüz? } \\
\hline \multicolumn{2}{|l|}{ Evet } & 205 & 75.36 \\
\hline \multirow{3}{*}{ Gerekçe } & Hayat Kurtarma & 123 & 45.22 \\
\hline & Dini Duygular & 33 & 12.13 \\
\hline & İnsanlara Yardımcı Olma & 49 & 18.01 \\
\hline \multicolumn{2}{|l|}{ Hayır } & 67 & 24.64 \\
\hline \multirow{2}{*}{ Gerekçe } & Vücuduna Müdahalede Bulunulmasını İstememe & 52 & 19.12 \\
\hline & Ailenin Organ Bağışına İzin vermemesi & 15 & 5.52 \\
\hline \multicolumn{4}{|c|}{ Organ Bağışının Önemi } \\
\hline \multicolumn{2}{|c|}{ Toplumsal Dayanışma } & 152 & 55.88 \\
\hline \multicolumn{2}{|c|}{ Hayat Kurtarma } & 78 & 28.67 \\
\hline \multicolumn{2}{|c|}{ Yardımcı Olma } & 42 & 15.44 \\
\hline \multicolumn{4}{|c|}{ Organ bağışında bulunmak için neler gereklidir? } \\
\hline \multicolumn{4}{|c|}{ Doğru bilinenler } \\
\hline \multicolumn{2}{|l|}{ Yaş } & 180 & 66.17 \\
\hline \multicolumn{2}{|l|}{ Aile İzni } & 72 & 26.47 \\
\hline \multicolumn{2}{|c|}{ Kişisel Karar } & 52 & 19.11 \\
\hline \multicolumn{2}{|c|}{ Doku Uyuşması } & 48 & 17.64 \\
\hline \multicolumn{4}{|c|}{ Yanlış bilinenler } \\
\hline \multicolumn{2}{|c|}{ Kendi Ailemizden Olması } & 43 & 15.80 \\
\hline \multicolumn{2}{|c|}{ Bağışlanabilen Organlar } & 10 & 3.67 \\
\hline
\end{tabular}

Çalışmaya katılan öğrencilerden \%45.2'si 'Hayat Kurtarma', \%12.13'ü 'Dini Duygular', \%18.01'i 'İnsanlara Yardımcı Olma' düşünceleri sebebiyle organlarını bağışlamayı düşünmektedir. Organ bağışında bulunmak isteyen öğrencilerin gerekçelerinden örnekler aşağıda sunulmuştur:

'Evet. [organ bağışında bulunmak isterim]. Çünkü bir hayat kurtarmak ve insanların yeniden yaşamaları için...' (Hayat kurtarma kategorisi- Öğrenci 129)

'Evet bulunmak isterim. Çünkü, eğer bir kişinin böbrekleri çalışamaz duruma gelmişse o kişiye organ bağışı yapılması gerekir. Biz eğer bu insana organ bağışı yaparsak Allah katında sevaba girmiş oluruz.' (Dini Duygular kategorisi- Öğrenci 13)

'Organ bağışında bulunmak isterim çünkü insanlar bu şekilde hayata tutunuyor ve insanlara yeni bir şans veriyoruz.' (İnsanlara yardımcı olma kategorisi- Öğrenci 21)

Öğrencilerden \%19.11'i 'Vücuduna müdahalede bulunulmasını istememe', \%5.51'i ise 'Ailesinin Organ Bağışına izin vermemesi sebebiyle organlarını bağışlamayı düşünmediğini ifade etmiştir. Organ bağışında bulunmak istemeyen öğrencilerin gerekçelerinden örnekler aşağıda sunulmuştur: 
'Hayır istemezdim. Çünkü ailem buna izin vermez' (Ailenin organ bağışına izin vermemesi kategorisi, Öğrenci 69)

'Hayır istemezdim çünkü vücudumun parçalanabileceğinden korkuyorum.' (Vücuduna Müdahalede Bulunulmasını İstememe kategorisi, Öğrenci 199)

Organ bağışının önemi konusunda ise öğrencilerin \%55.88'i 'Toplumsal Dayanışma', \%28.67'si 'Hayat Kurtarma' ve \%15.44'ü 'Yardımcı Olma' açısından organ bağışını önemli görmektedir. Öğrencilere, organ bağışının önemi konusundaki düşünceleri sorulduğunda öğrencilerin verdikleri cevaplardan örnekler, aşağıda sunulmuştur:

\footnotetext{
'Organ bağışı insanlara çok faydalı olur. Mesela bir insanın organa ihtiyacı var, biz organlarımızı bağışladığımızda o insan da o organdan faydalanır. Yarın benim de organa ihtiyacım olduğunda başkasının bağışladığı organ da benim hayatımı kurtarabilir.’ (Toplumsal dayanışma kategorisi, Öğrenci 68)

'Organ bağışı önemlidir çünkü organ bağışı olmasaydı insanın böbreği ya da karaciğer çalışamaz hale geldiğinde ölecekti. Biz organ bağışı yaparak o insanın hayatını kurtarmış oluruz.' (Hayat kurtarma kategorisi, Öğrenci 76)

'Organ bağışı önemlidir çünkü insanlara yardımı kolaylaştırır.' (Yardımcı olma kategorisi, Öğrenci 23)
}

Organ bağışında bulunmak için neler gerekli olduğuna dair sorulan soruya öğrencilerden \%66.17'si 'Yaş', \%26.47'si 'Aile İzni', \%19.11'i 'Kişisel Karar' ve \%17.64'ü 'Doku Uyuşması' cevaplarını vermişlerdir. Burada belirlenen 'aile izni' kategorisi, organ bağışında bulunmak için aile izninin gerekli olduğu şeklinde algılanmamalıdır. Organ bağışında bulunabilmek için 1979 tarih ve 2238 no'lu yasa gereği 18 yaşında ve akıl sağlığ 1 yerinde olma şartı vardır. Ancak ülkemizde organların resmi olarak bağışlanabilmesi için bireylerin organ bağışı kartının yanında, bireylerin birinci derecede yakınlarının da onayı gerekmektedir (Polat, 2016). Dolayısıyla 'aile izni' kategorisi bu doğrultuda oluşturulmuştur. $\mathrm{Bu}$ kategorideki cevaplar, organ bağışlanabilmesi için ailenin izninin gerekli oluğu yönündedir. Bu doğru cevapların yanı sıra, öğrencilerin \%15.80'i organ bağışında bulunulacak kişinin 'Kendi Ailemizden Olması' gerektiğini belirtmiş ve \%3.67'si ise 'Bağışlanabilen Organlar' konusunda yanlış bilgilere sahip olduğu görülmüştür. Örneğin, öğrencilerden bazıları karaciğer kendini 'yenilediği' için bu organın nakline ihtiyaç duyulmadığını ifade etmişlerdir.

\section{Sonuç ve Tartışma}

$\mathrm{Bu}$ çalışmada, ortaokul öğrencilerinin organ bağışı ve nakli konusundaki görüşleri incelenmiştir. Çalışmanın sonuçları, öğrencilerin bu konuların programda yer almadığını düşündüklerini (\%52.2), organ bağışı konusundaki bilgi sahibi olmadıklarını (\%59.2) ve organ bağışı konusunda gerekli şartları bilmediklerini (\%71) ortaya koymuştur. Yine katılımcıların önemli bir kısmının (\%30.3), organ bağışında bulunabilmek için gerekli yaş sınırı olan ve 1979 tarih ve 238 no'lu yasa ile belirlenen 18 yaşında olma koşulunu bilmediği ancak bu konuda bilgi almaya istekli oldukları (\%77.2) görülürken çoğu öğrencinin (\%83.1) ise doktor, hemşire gibi sağlık personelinden bilgi almak istedikleri; bununla birlikte sadece din görevlilerinden bilgi almak isteyenlerin (\%5) ve sağlik personeli ile birlikte din görevlilerinden bilgi almak isteyen öğrencilerin de (\%29) bulunduğu belirlenmiştir. Bu durum, organ nakli ve organ bağışı durumlarının sadece sağlı personelinin değil aynı zamanda toplumsal açıdan ve dini açılardan küçük yaşlardan itibaren çocukların zihinlerinde soru işaretleri oluştuğu 
şeklinde yorumlanabilir. Din görevlilerinden bilgi almak isteyen öğrencilerin olması, organ bağışı ve nakli konusunda dini açıdan çekincelerin de bulunabileceği şeklinde yorumlanabilir. Nitekim var olan çalışmaların sonuçları da bu bulguyla örtüşmektedir. Örneğin katılımcılardan organ bağışı ve organ nakli yaptırmak istemeyenlerin ya da bu konularda kararsız olan bireylerin gerekçe olarak "dinen sakıncalı olması" ve "örf adetlerin baskısı” gibi gerekçeler öne sürdükleri görülmektedir (Çetin \& Harman, 2012; Gökçe ve diğerleri, 2016; Kavurmacı ve diğerleri, 2014; Kılıç ve diğerleri, 2010; Sıpkın ve diğerleri, 2010; Toru \& Ayada, 2014). Örneğin, öğrenci velileriyle yapılan diğer bir çalışmada öğrenci velilerinin organ bağışında bulunmaya istekli olmalarının kültürel ve dini faktörlerden etkilendiği rapor edilmiştir (Gökçe ve diğerleri, 2016). Bu çalışmada elde edilen bulgular da küçük yaşlardan itibaren çocukların zihinlerinde organ bağgşı ve nakli ile ilgili soru işaretleri oluştuğunu ve bu soru işaretlerinin giderilmesi adına sağlık personelinin yanı sıra din görevlilerinden de bilgi almayı talep ettiklerini göstermektedir. $\mathrm{Bu}$ bireylerin ilerleyen yaşlarda organ bağışı ve nakli konusunda kararsız kalmaları veya olumsuz tutum içerisinde olmaları, bireylerin küçük yaşlardan itibaren organ bağışı ve nakli konusunda doğru kaynaklardan özellikle sağlık personelinden bunun yanında da din görevlilerinden yeterli bilgi alamamalarından kaynaklanabiliyor olabilir.

Yine çalışmadan elde edilen diğer önemli sonuç ise öğrencilerin nakil olabilecek organlar hakkındaki farkındalıklarının değişiklik göstermesidir. Örneğin, öğrencilerin önemli bir çoğunluğu böbrek (\%74.3), karaciğer (\%60.7) ve kalp (\%47.8) naklinden haberdar iken kemik iliği (\%24.3) ve kornea (\%16.2) naklinin yapılabileceğinden haberdar olan öğrenci sayısı daha azdır. Bu durum yetişkinlerle yapılan çalışmaların bulguları ile paralellik göstermektedir (Bedi ve diğerleri, 2005; Efil ve diğerleri 2013). $\mathrm{Bu}$ durum, böbrek, karaciğer ve kalp nakli gibi haberlerin medyada daha fazla yer almasından kaynaklanıyor olabilir. İlgili alanyazın da sıklıkla bireylerin organ bağışı ile ilgili bilgilerini televizyon veya internetten edindiğini rapor etmektedir (bkz. Özer ve diğerleri, 2008; Yazıcı ve diğerleri, 2015). Bu çalışmadaki öğrencilerin yarısından fazlası organ bağışı ve nakli ile ilgili bilgileri internetten (\%55.9) ve televizyondan (\%57.7) edindiklerini ifade etmişlerdir. $\mathrm{Bu}$ da öğrencilerin bazı organların nakli konusundaki farkındalıklarının daha yüksek olmasının sebebi olabilir.

Öğrencilere organlarını bağışlamayı düşünüp düşünmedikleri sorulduğunda, öğrencilerin hayat kurtarma (\%45.2), dini duygular (\%12.13) ve insanlara yardımc1 olmak (\%18.01) amaçlı olarak organ bağışında bulunmak istediklerini ifade etmişlerdir. $\mathrm{Bu}$ durum, ilgili alanyazında organ bağışının faydaları konusunda rapor edilen "başkalarının hayatlarını kurtarmak", "hasta bireyleri sağlığına kavuşturmak", "çürüyüp gidecek organların işe yaraması", "insanlığa hizmet" şeklinde ifade edilen katılımcı görüşleri ile örtüşmektedir (Bölükbaşı ve diğerleri, 2004; Cebeci, Sucu-Dağ, \& Karazeybek, 2015; Demir Doğan ve diğerleri, 2016; Harman \& Çökelez, 2017; K1lıç ve diğerleri, 2010; Koçak ve diğerleri, 2010; Gökçe ve diğerleri, 2008; Özmen ve diğerleri, 2007). Benzer şekilde Özer ve diğerleri (2016) yedinci sınıf öğrencileriyle yaptıkları çalışmada öğrencilerin organ bağışını hayat kurtarma olarak gördüğünü, yardımlaşma ve paylaşma duygularını güçlendirdiğini düşündüklerini belirlemiştir. Bununla birlikte bu çalışmada, vücuduna müdahalede bulunulmasını istemeyen (\%19.11) ve ailesinin organ bağışına karşı olduğunu ifade eden (\%5.51) öğrenciler mevcuttur. Benzer şekilde alanyazında katılımcıların bir kısmının organ bağışı konusunda olumsuz görüş ifade 
ettikleri, bunun nedenini ise "vücut bütünlüklerinin bozulacağı", "sağlık personeline güvenmemeleri", "vicdanen rahat olmamaları", "yetersiz bilgilendirme", "dinen sakıncalı olması" ve "örf adetlerin baskısı" gibi sebeplere dayandırdıkları görülmüsstür (Çetin \& Harman, 2012; Kavurmacı ve diğerleri, 2014; Kılıç ve diğerleri, 2010; Sıpkın ve diğerleri, 2010; Özmen ve diğerleri, 2007; Toru \& Ayada, 2014).

Organ bağışı konusunda öğrencilerin doğru bildikleri kavramlar arasında yaş (\%66.17), aile izni (\%26.47), kişisel karar (\%19.11) ve doku uyuşması gerekliliği (\%17.64) bulunurken, bazı öğrencilerin organ bağışı bulunabilmek için kendi ailesinden olmas1 gerektiğini düşündükleri $(\% 15.80)$ ve bağışlanabilen organlar konusunda (\%3.67) hatalı bilgilere sahip oldukları belirlenmiştir. Organ bağışı konusunda bilgi düzeyini belirlemeye yönelik gerçekleştirilen çalışmaların bulguları farklılık göstermektedir. Örneğin çalışmaların bir kısmı organ bağışı konusunda bireylerin bilgi düzeylerinin yetersiz olduğunu belirtirken (bkz. Balc1 \& Şahingöz, 2014; Toru \& Ayada, 2014; Kılıç ve diğerleri, 2010; Özkan \& Yılmaz, 2009; Yaşar ve diğerleri, 2008), bazı çalışmalar ise bireylerin bu konuda bilgili olduklarını ortaya koymuşlardır (Aytaş ve diğerleri, 2011; Tarhan ve diğerleri, 2012). Örneğin, Tarhan ve diğerleri (2012) lise öğrencileriyle gerçekleştirdiği çalışmada ise lise öğrencilerinin yarısından fazlasının (\%58) organ bağışı konusunda bilgi sahibi olduklarını belirlemişlerdir. Bu çalışmada da öğrencilerin önemli bir kısmı, organ nakli için gerekli şartları bilmekle birlikte, konuyla ilgili yanlış bilgilere de sahiptir. Bu durum da, organ bağışı ve nakli konusunda bireylerin bilgilendirilmesinin önemini vurgulamak açısından önem arz etmektedir.

Yapılan ulusal ve uluslararası düzeydeki çalışmalarda eğitimli bireylerin organ bağışı ve nakli konusunda daha bilinçli, istekli oldukları ve daha olumlu tutumlara sahip oldukları görülmüştür (Aytaş ve diğerleri, 2011; Bedi ve diğerleri, 2015; Burra ve diğerleri, 2005; Figueroa ve diğerleri, 2013; Kavurmacı ve diğerleri, 2014; Öztürk Emiral ve diğerleri, 2017; Reville ve diğerleri, 2013; Siebelink ve diğerleri, 2002; 2011; 2017; Yaşar ve diğerleri, 2008). Dolayısıyla küçük yaşlardan itibaren organ bağışı ve nakli konusunda bireylerin farkındalıklarının arttırılması gerekmektedir. Örneğin, Siebelink ve diğerleri (2011) 12-15 yaş aralığındaki çocukların organ bağışı konusunda düşünebilecek yetilere sahip olduğunu ve bu konuda düşünmeye istekli olduğunu belirlemiştir. Dolayısıyla bu konuların ortaokul fen bilimleri programına dahil edilmesi öğrencilerin bu konularda bilinçli olarak yetişmelerini sağlayacaktır. Bu konuda bilinçli yetişen öğrencilerin organ bağgşı ve nakli konusunda daha olumlu tutumlara sahip olması beklenmektedir. Aynı zamanda, yapılan çalışmalar organ bağışı ve nakli konusunda uygulanan eğitsel programların öğrencilerin bu konudaki tutumlarını ve bilgi düzeylerini olumlu yönde etkilediğini rapor etmiştir (bkz. Milaniak ve diğerleri, 2010; Özer ve diğerleri, 2008; Shu ve diğerleri, 2011; Siebelink ve diğerleri, 2011; 2017). Özellikle Siebelink ve diğerleri (2017) 10-11 yaş aralığından itibaren öğrencilerin organ bağışı konusunda bilgilendirilebileceğini ifade etmiştir. Bu nedenle organ bağışı ve organ nakli konuları erken yaşlardan itibaren fen bilimleri programına dahil edilmelidir. Her ne kadar öğretmenlerin bir kısmı öğrencilerin bu konuları konuşmak için çok küçük olduğunu ifade etseler de (Siebelink ve diğerleri, 2017), öğretmenlerin ve öğretmen adaylarının önemli bir kısmı bu konuların fen bilimleri programında yer alması gerektiğini vurgulamaktadır (Siebelink ve diğerleri, 2017; Evren Yapıcıŏ̆lu, 2016; Toraman \& Aydın, 2013). Nitekim, Milli Eğitim Bakanlığının 2013 ve 2017 yıllarında 
yaptığı düzenlemelerle ilköğretim düzeyinde bu konuları fen bilimleri derslerine kazanım olarak eklemesi de öğrencilerin bu konularda küçük yaşlardan itibaren bilinçli bir şekilde yetişmeleri gerektiğini göstermektedir.

\section{Öneriler}

Ortaokul öğrencilerinin organ bağışı ve nakline yönelik görüşlerinin incelendiği bu çalışma, mevcut programda öğrenim gören öğrencilerin organ bağışı ve organ nakli konusundaki halihazırdaki durumlarını göstermeleri açısından önemlidir. 2013 yılından itibaren uygulanmakta olan ve 2017 yılında yenilenen Fen bilimleri öğretim programında vurgulanan 'organ bağışının toplumsal önemi' konusunda öğrencilerin bilgi düzeyleri ve farkındalıklarının araştırıldığı bu çalışmada aşağıdaki öneriler getirilmiştir:

Organ, Doku Nakli ve Diyaliz Hizmetleri Daire Başkanlığı verilerine göre organ bağışı bekleyen kişi sayısı 25 binin üzerinde iken, beyin ölümü gerçekleşen bireylerin sadece yaklaşık \%20'lik bir kısmının (\%26.06 erkeklerde ve \%22.77 kadınlarda) organlarının bağışlandığı ve \%70'inin ise organlarının bağışına izin verilmediği görülmektedir. Yurtdışındaki organ bağıșı oranlarına bakıldığında bu oranların hayli yüksek olduğu (Örneğin, İspanya'da bu oranın \%50 civarında olduğu) görülmüştür (Şişli Hamidiye Etfal Eğitim ve Araştırma Hastanesi Organ ve Doku Nakli Koordinatörlüğü, 2018). Bu durum, organ bağışının öneminin toplumsal olarak vurgulanmasını ve organ bağışında bulunan/bulunmak isteyen birey sayısının arttırılmasını gerekli kılmaktadır. Organ bağıșı sayısındaki artış hem öğretmenlerin hem de öğrencilerin farkındalıklarının artmasıyla mümkündür.

Öğretmenlerin bu konunun önemi konusundaki farkındalıklarının arttırılması önemlidir. Geleceğin öğretmenleri olan öğretmen adaylarının yapılan çalışmalarda organ bağışı konusunu sosyobilimsel konular içerisinde ele aldığı görülmüştür (Evren Yapıcıoğlu, 2016; Harman \& Çökelez, 2017; Toraman \& Aydın, 2013). Dolayısıyla, organ bağışı ve naklinin öğretimi, sosyobilimsel konuların öğretimi kapsamında çeşitli yöntem ve teknikler kullanılarak ele alınabilir. Öğretmen adaylarının bu konuda daha bilinçli olarak yetiştiği göz önüne alındığında, halihazırda görev yapan öğretmenlere yönelik sosyobilimsel konular temelli hizmet içi eğitim içeriği hazırlanması faydalı olabilir. Böylece fen bilimleri öğretmenlerinin bu konuların öğretimine ve bu konuların erken yaşlardan itibaren fen bilimleri programına dahil edilmesine yönelik farkındalıkları arttırılabilir. Yine fen bilimleri öğretmenleri, organ bağışı ve organ nakli konularının işlendiği derslere bir sağlık çalışanı (hekim, hemşire) davet ederek öğrencilerin konu ile ilgili daha ayrıntılı bilgileri konu uzmanlarından öğrenmelerini sağlayabilir.

$\mathrm{Bu}$ çalışma, temelde belli bir bölgede öğrenim görmekte olan ortaokul öğrencilerinin organ bağışı ve nakline yönelik görüşlerini ortaya çıkarmayı hedeflemekle birlikte, araştırma daha fazla katılımcı ve daha farklı bölgelerde öğrenim gören öğrencilerle gerçekleştirilebilir. Yine bu çalışma, katılımcıların görüşlerini ortaya çıkarmayı hedeflemekte ve bu görüşlerin değiştirilmesine yönelik herhangi bir eğitsel uygulama içermemektedir. Halbuki yapılan çalışmalar eğitsel programların öğrencilerin organ bağışı ve nakline yönelik olarak görüşlerini olumlu yönde etkilediği ve özellikle küçük yaşlardan itibaren bu konuların fen bilimleri dersi programına dahil edilmesi gerektiğini vurgulamaktadır (bkz. Milaniak ve diğerleri, 2010; Reville ve diğerleri, 
2013; Siebelink ve diğerleri, 2011; 2017; Tarhan ve diğerleri, 2012). Dolayısıyla organ bağışı ve nakline yönelik geliştirilecek eğitsel programlar, öğrencilerin bu konulardaki farkındalığının arttırılmasına hizmet edebilir ve bu konularda yapılacak çalışmalara yol gösterici olabilir. 


\section{Summary}

Purpose and Significance: Raising informed generations about organ donation and organ transplantation is possible with informing students about organ donation from beginning of early ages. As Burra et al. (2005) indicated one of the main problems in organ donation is the insufficient number of people who donate their organs. Thus, public opinions about organ donation and organ transplantation have gained a new direction. In the literature, there have been numerous studies conducted with nurses (Aytaş, Ünal, \& Kartalc1, 2011; Balcı \& Şahingöz, 2014), medical school students (e.g., Bedi et al., 2015; Burra et al. 2005; Koçak, Aktaş, Şenol, Kaya, \& Bilgin, 2010; Toru \& Ayada, 2014), nursery school students (e.g., Altınkaynak, Ekinci, Kaya, Uzun, \& Demir Doğan, 2016; Bulletin, 2011; Savaşer, Mutlu, Çağlar, Doğan, \& Canbulat, 2012) and graduate and undergraduate students (e.g., Bölükbaşı, Eyüpoğlu, \& Kurt, 2004; Kılıç, Koçak, Türker, Gürpınar, \& Gülerik) as well as with high school and middle school students (Özer, Kilci, \& Gökçe, 2016; Siebelink et al., 2002, 2011, 2017; Sanner, 2002). In their study, Ozer et al. (2016) investigated middle school 7th grade students' opinions about organ donation and they revealed that students thought that organ donation 'saves lives', strengthen feelings of sharing and empathy. In another study, Siebelink et al. (2011) indicated the students aged 12 to 15 are capable of talking about organ donation and eager to discuss this issue with their parents. Moreover, there are studies which reported that educational programs enhanced students' awareness about organ donation (Reville et al., 2013; Siebelink et al., 2017). Revised middle school science curriculum in Turkey (both in 2013 and in 2017) have emphasized the importance of organ donation for the sake of social solidarity (Ministry of National Education [MoNE], 2013; 2017). In addition, study findings supported that informed people are more aware about the importance of organ donation (e.g., Barcellos, Arauio, \& Costa, 2005; Öztürk Emiral, 2017). Thus, it is important to integrate the concepts of organ donation and organ transplantation into middle school curriculum. Based on this idea, we explored middle school students' opinions about organ donation and transplantation.

Methods: We used survey design in this study. A total of 272 middle school students from three different schools in Usak city participated in the study. After literature review, a questionnaire which was prepared by the authors was administrated to the students. Descriptive analysis (frequencies and percentages) was used for data analysis.

Results: The results indicated that most of the students are not aware of the fact that organ donation and transplantation topics are included in the science in the program. Only $21 \%$ of the students were aware of these issues are included. While most of the students indicated that they did not know the requirements of organ donation $(71 \%)$, $59.2 \%$ of the students indicated that they are not knowledgeable about organ donation. While students were aware of the kidney (74.3\%), liver (60.7\%) and heart $(47.8 \%)$ transplantation; less students were knowledgeable about bone marrow (24.3\%) and cornea (16.2\%) transplantation. Majority of students indicated that they would like to be informed about organ transplantation $(77.2 \%)$. More than half of the students wanted to be informed by doctors $(66.9 \%)$ and nurses $(16.2 \%)$. There were also students who 
wanted to be informed by a group of experts including doctors, nurses and religious officials $(29 \%)$. While many students indicated that they would like to donate their organs because they would like to "save lives" (45.2\%), "religious faith" (12.13\%) and "helping people" (18.01\%). The participants thought that organ donation is important because it helps "social solidarity" (55.88\%), "save lives" (28.67\%) and "help people" $(15.44 \%)$. There were also some students who would like to not donate their organs because they do not wish to "interfere with their body integrity" (19.11\%) and "their family would not allow" (5.51\%).

Discussion and Conclusions: The results of this study indicated that even most of the students by doctors $(66.9 \%)$ and nurses $(16.2 \%)$, there were also students who wanted to be informed by a group of experts including doctors, nurses and religious officials (29\%). This shows that students also wanted learn how religious officials perceive organ donation process. This also shows that students' ideas about organ donation are influenced by religious and social factors from the beginning of early ages. This finding confirms the results of existing studies (see; Çetin \& Harman, 2012; Kavurmac1 et al., 2014; Kılıç et al., 2010; Sıpkın et al., 2010; Toru \& Ayada, 2014). In this studies; participants were reported to be hesitant or have negative attitudes towards organ donation because they find organ donation as "religiously objectionable", and they perceived "the pressure of culture" (Çetin \& Harman, 2012; Kavurmac1 et al., 2014; Kılıç et al., 2010; Sıpkın et al., 2010; Toru \& Ayada, 2014). For instance, Gokce et al. (2016) indicated that parents of seventh grade students showed willingness to donate their organs even they perceived it is related with cultural and religious factors. Another significant finding of this study showed that while students were aware about the kidney (74.3\%), liver $(60.7 \%)$ and heart $(47.8 \%)$ transplantation; less students were knowledgeable about bone marrow $(24.3 \%)$ and cornea $(16.2 \%)$ transplantation. This finding is parallel with the literature which shows that participants were mainly aware of kidney, liver, and heart transplant (Bedi et al., 2005; Efil et al., 2013). This might be related with that there are plenty of about successful kidney, heart or liver transplant stories news in the media. As the students in our study as well as other participants in aforementioned studies mainly reported that they are informed about organ donation and transplantation by television or internet. To conclude, this study shows that it is important raise students who are aware about the importance of organ donation and transplantation issues as this issues are included in both middle school science curriculum (Ministry of National Education [MoNE], 2013; 2017). Even some teachers thought that the students could be young to discuss organ donation and transplantation issues, study findings suggested that students aged 10-11 are capable of discussing these issues (Siebelink et al., 2011; 2017). 


\section{Kaynakça}

Aytaş, Ö., Kartalcı, Ş., \& Ünal, S. (2011). Bir grup hemşirenin sosyodemografik verileri ve tükenmişlik düzeyleri bağlamında organ bağışına bakış açıları. İnönü Üniversitesi Tıp Fakültesi Dergisi, 18(1), 26-32.

Balcı, E., \& Şahingöz, M. (2014). Hemşirelerin organ bağışına bakışları. Cumhuriyet Medical Journal, 36(4), 503-511.

Bedi, K. K., Hakeem, A. R., Dave, R., Lewington, A., Sanfey, H., \& Ahmad, N. (2015). Survey of the knowledge, perception, and attitude of medical students at the University of Leeds toward organ donation and transplantation. Transplantation Proceedings, 47(2), 247-260.

Bölükbaş, N., Eyüpoğlu, A., \& Kurt, P. (2004). Organ bağışı hakkında üniversite öğrencilerinin düşünceleri. Journal of Experimental and Clinical Medicine, 21(2), 73-77.

Burra, P., De Bona, M., Canova, D., D'Aloiso, M. C., Germani, G., Rumiati, R., ... \& Ancona, E. (2005). Changing attitude to organ donation and transplantation in university students during the years of medical school in Italy. Transplantation Proceedings, 37(2), 547-550.

Cebeci, F., Dăg, G. S., \& Karazeybek, E. (2015). Undergraduate nursing students' opinions and attitudes toward organ donation: A survey in a Turkish University. Journal of Nursing Education and Practice, 5(9), 83-89.

Çetin, G., \& Harman, Ö. (2012). Lise öğrencilerinin organ nakli ve organ bağış1 konusundaki bilgi ve tutumları. Ĕ̈itim ve Öğretim Araştırmaları Dergisi, 1(2), 172-177.

Demir Doğan, M., Uzun, İ., Kaya, N., Ekinci, H., \& Altınkaynak, M. (2016). Üniversite öğrencilerinin organ bağışına bakış açısı ve bilgi düzeyleri. Sağllk Bilimleri ve Meslekleri Dergisi, 3(2), 99-105.

Efil, S., Sise, S., Üzel, H., \& Eser, O. (2013). Afyon ilinde halkın ve Afyon Kocatepe Üniversitesi Tıp Fakültesi sağlık çalışanlarının organ bağgşı konusuna ilgilerinin değerlendirilmesi. Gümüşhane Üniversitesi Sağllk Bilimleri Dergisi, 2(3), 361384.

Fraenkel, J. R., Wallen, N. E., \& Hyun, H. (2011). How to design and evaluate research in education (8th ed.). New York: McGrawHill.

Figueroa, C. A., Mesfum, E. T., Acton, N. T., \& Kunst, A. E. (2013). Medical students' knowledge and attitudes toward organ donation: Results of a Dutch survey. Transplantation proceedings, 45(6), 2093-2097.

Gökçe, N., Özer, H., \& Kilci, Z. (2016). Organ donation according to the students and their families in example of the social studies course. Anadolu Journal of Educational Sciences International, 6(1), 84-109.

Harman, G., \& Çökelez, A. (2017). Fen bilgisi öğretmen adaylarının sosyo-bilimsel bir konu olan organ bağışına yönelik metaforik algıları. Uşak Üniversitesi Sosyal Bilimler Dergisi, 10(1), 55-70.

Kara, S., Salman, Z., \& Öngel, K. (2012). Süleyman Demirel Üniversitesi Tip Fakültesi sağlık personelinin organ bağışına bakışı. Ankara Sağlık Hizmetleri Dergisi, 11(1), 33-9. 
Kavurmacı, M., Karabulut, N., \& Koç, A. (2014). Üniversite öğrencilerinin organ bağışı hakkındaki bilgi ve görüşleri. Hemşirelikte Eğitim ve Araştırma Dergisi, 11(2), 15-21.

Kaya, E., Sezek, F., Akman, Z., Erbil, B., Aslan, B., Özgen, R., \& Keleş, Ö. (2015). Üniversite öğrencilerinin öğrenim gördükleri alanlara göre organ nakli ve bağış1 ile ilgili görüşleri. EKEV Akademi Dergisi, 62, 471-486.

Kılıç, S., Koçak, N., Türker, T., Gürpınar, H., Gülerik, D., \& Okulu, G. H. Y. (2010). Kız üniversite öğrencilerinin organ bağışı konusundaki tutumları ve bu tutumlarına etki eden faktörler. Gülhane Tıp Dergisi, 52(1), 36-40.

Klop, T., \& Severiens, S. (2007). An exploration of attitudes towards modern biotechnology: A study among Dutch secondary school students. International Journal of Science Education, 29(5), 663-679.

Koçak, A., Aktaş, E. Ö., Şenol, E., Kaya, A., \& Bilgin, U. E. (2010). Ege Üniversitesi Tıp Fakültesi öğrencilerinin organ nakli ve bağışı hakkındaki bilgi düzeyi. Ege Tip Dergisi, 49(3), 153-160.

Milaniak, I., Przybylowski, P., Wierzbicki, K., \& Sadowski, J. (2010). Organ transplant education: the way to form altruistic behaviors among secondary school students toward organ donation. Transplantation Proceedings, 42(1), 130-133.

Miles, M. B., ve Huberman, A.M. (1994). Qualitative data analysis: An expanded sourcebook, (2nd ed.). California: Sage Publications.

Milli Eğitim Bakanlığı (MEB). (2013). Fen bilimleri dersi öğretim programı. (Ilkokul ve ortaokul 3, 4, 5, 6, 7 ve 8. sinıflar) Ankara: Milli Eğitim Bakanlığı.

Milli Eğitim Bakanlığı (MEB). (2017). Ilköğretim kurumları fen bilimleri dersi öğretim programı (3, 4, 5, 6, 7 ve 8. sınıflar). Ankara: Milli Eğitim Bakanlığı.

Organ, Doku Nakli ve Diyaliz Hizmetleri Daire Başkanlığı (2018). Kadeverik Donör sayıları. https://organkds.saglik.gov.tr/KamuyaAcikRapor.aspx?q=YOBIS adresinden edinilmiştir.

Özdağ, N. (2004). Halkın organ bağışı ve nakline bakışı. Nefroloji Hemşireliği Dergisi, 1(1), 46-50.

Özer, F. G., Karamanoğlu, A. Y., Beydağ, K. D., Fidancığlu, H., Akıncı, E., Şanlı, İ, ... \& Urak, S. (2008). Sağlık yüksekokulunda öğrenim gören bir grup öğrencinin organ nakli/bağışına yönelik görüşleri ve bilgi düzeylerine eğitimin etkisi. TSK Koruyucu Hekimlik Bülteni, 7(1), 39-46.

Özkan, S., \& Yılmaz, E. (2009). Hasta yakınlarının organ bağışı ile ilgili bilgi ve tutumlar1. Aile ve Toplum, 11(5), 18-29.

Özmen, D., Çetinkaya, A. Ç., Sarızeybek, B., Zeybek, A. (2008). Celal Bayar Üniversitesi Manisa Sağlık Yüksekokulu öğrencilerinin organ bağgşına ilişkin bilgi ve görüşleri. Türkiye Klinikleri Journal of Medical Sciences, 28, 311-318

Özpulat, F. (2017). Üniversite öğrencilerinin kan ve organ bağışına ilişkin düşünceleri. Săgllk Bilimleri ve Meslekleri Dergisi, 4(2), 71-79. 
Öztürk Emiral., Atalay, B. I., Altunok, H., Gokler, M. E., Onsuz, M. F., \& Metintas, S. (2017). Development of a reliable and valid organ tissue donation and transplantation knowledge scale. Transplantation Proceedings, 49(2), 260-266.

Polat, K.Y. (2016). Organ bağışı ile ilgili bilmemiz gerekenler. https://www.memorial.com.tr/saglik-rehberleri/organ-bagisi-ile-ilgili-bilmenizgerekenler/ adresinden edinilmiştir.

Reville, P., Zhao, C., Perez, T., Nowacki, A. S., Phillips, D., Bowen, G., ... \& Askar, M. (2013). A student leadership model for promoting educational programs in organ donation and transplantation. Transplantation Proceedings, 45(4), 12871294.

Sadler, T. D., \& Zeidler, D. L. (2004). The morality of socioscientific issues: Construal and resolution of genetic engineering dilemmas. Science Education, 88(1), 4-27.

Sadler, T. D., \& Zeidler, D. L. (2005). Patterns of informal reasoning in the context of socioscientific decision making. Journal of Research in Science Teaching, 42(1), 112-138.

Sanner, M. A. (2002). A Swedish survey of young people's views on organ donation and transplantation. Transplant International, 15(12), 641-648.

Savaşer, S., Mutlu, B., Çağlar, S., Doğan, Z., \& Canbulat, N. (2012). Hemşirelik son sınıf öğrencilerinin organ bağışına bakışları. Florence Nightingale Hemşirelik Dergisi, 20(1), 1-9.

Shu, J., Fok, T., Mussen, L., Mohamed, M., Weernink, C., Abbott, C., ... \& Luke, P. P. W. (2011). Impact of the educational resource one life... many gifts on attitudes of secondary school students towards organ and tissue donation and transplantation. In Transplantation Proceedings, 43(5), 1418-1420.

Sıpkın, S., Şen, B., Akan, S., \& Malak, A. T. (2010). Onsekiz Mart Üniversitesi Tıp Fakültesi, İlahiyat Fakültesi ve Güzel Sanatlar Fakültesi öğretim elemanlarının organ bağışına bakış açılarının incelenmesi. Adnan Menderes Üniversitesi Tip Fakültesi Dergisi, 11(1), 19-25.

Siebelink, M. J., Albers, M. J., Roodbol, P. F., \& van de Wiel, H. (2012). Key factors in paediatric organ and tissue donation: An overview of literature in a chronological working model. Transplant International, 25(3), 265-271.

Siebelink, M. J., Geerts, E. A., Albers, M. J., Roodbol, P. F., \& van de Wiel, H. B. (2011). Children's opinions about organ donation: A first step to assent?. The European Journal of Public Health, 22(4), 529-533.

Siebelink, M. J., Verhagen, A. E., Roodbol, P. F., Albers, M. J., \& Van de Wiel, H. B. (2017). Education on organ donation and transplantation in primary school; Teachers' support and the first results of a teaching module. PloS One, 12(5), 29.

Şen, H., \& Özaydın, Ö. (2004). Eskişehir ilindeki bireylerin organ bağışı hakkındaki düşünceleri ile sosyo-ekonomik nitelikleri arasındaki ilişki yapısının incelenmesi. Eskişehir Osmangazi Üniversitesi Sosyal Bilimler Dergisi, 5(1), 96116. 
Strauss, A., \& Corbin, J. M. (1990). Basics of qualitative research: Grounded theory procedures and techniques. Sage Publications, Inc.

Şişli Hamidiye Etfal Eğitim ve Araştırma Hastanesi Organ ve Doku Nakli Koordinatörlüğü (2018). Bütün yönleriyle organ bağışl. http://sislietfaleah.saglik.gov.tr/TR,58819/organ-bagisi.html adresinden edinilmiştir.

Tarhan, M., Dalar, L., Yıldırımoğlu, H., Sayar, A., \& Altın, S. (2012). Zeytinburnu İlçesi'nde lise son sınıfta öğrenim gören öğrencilerin organ nakli ve bağışına yönelik bilgi düzeyleri ve tutumlarına bilgilendirmenin etkisi. Yoğun Bakım Dergisi, 3, 27-35.

Toraman, S., \& Aydın, H. (2013). Öğretmen Adaylarının Fen-Teknoloji-ToplumÇevre İlişkilendirmelerine Yönelik Görüşleri Bartın Üniversitesi Eğitim Fakültesi Dergisi, 2(2), 146-170.

Toru, Ü., \& Ayada, C. (2015). Dumlupınar Üniversitesi Tıp Fakültesi öğrencilerinin organ bağışı ve transplantasyona bakış açıları. International Journal of Basic and Clinical Medicine, 3(1), 9-15.

Evren Yapıcıŏlu, A. (2016). Fen bilimleri öğretmen adaylarının sosyobilimsel durum temelli öğretim yaklaşımı uygulamalarına yönelik görüşleri ve çalışmalarına yansıtmaları. Hacettepe Üniversitesi Ĕ̌itim Bilimleri Enstitüsü Ĕ̈itim Araştırmaları Dergisi, 2(2), 132-151.

Yaşar, M., Oğur, R., Uçar, M., Göçgeldi, E., Yaren, H., Tekbaş, Ö. F., \& Korkmaz, A. (2008). Bir Sağlık Meslek Yüksekokulu son sınıf öğrencilerinin organ bağışı konusundaki tutumları ve tutumlarına etki eden faktörler. Genel Tip Dergisi, 18(1), 33-37.

Yazıcı, S. Ö., Kavak, H. O., Kaya, E., Tekin, A., \& Kalaycı, I. (2015). Hemşirelik öğrencilerinin organ nakli ve bağışı konusunda bilgi ve düşüncelerinin belirlenmesi. Mehmet Akif Ersoy Üniversitesi Sağlık Bilimleri Enstitüsü Dergisi, $3(2), 66-76$. 